Received: 15 October 2014

Accepted: 5 November 2014

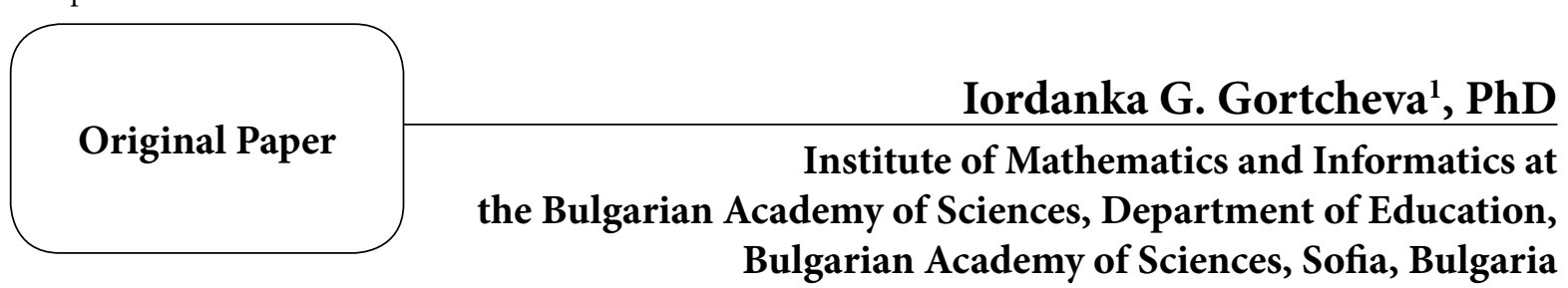

\title{
Mathematical and cultural messages from the period between the two world wars: Elin Pelin's story problems
}

\begin{abstract}
In the mid-thirties of XX c. the renowned Bulgarian writer Elin Pelin published the children's newspaper Path (in Bulgarian: Пъйекa) regularly including mathematical story problems. Their unusual imagery and plots were quite different from textbook math problems. The leading character Old-hand Stanyo loved to tell his neighbours' children stories in which he intertwined elements of mathematics or logic. Too lengthy sometimes, the story problems revealed various sides of culture to children and taught them to pay attention to detail, think logically, and not to neglect common sense. Whatever life situations were described, the moral was always the same - the knowledge of mathematics helped overcome obstacles. Elin Pelin's newspaper was circulated all around Bulgaria inspiring children from towns big and small to learn counting, divisibility of numbers, systems of linear equations, binary number system, etc. These topics continue to be in the scope of interests of contemporary students, teachers, and mathematics educators. Story problems of Elin Pelin's series, exemplary pieces of which are analyzed in the article, attract modern readers with the unique mathematical and cultural values of their time.
\end{abstract}

Key words: Elin Pelin, primary school, story problems, culture.

\section{Introduction}

Mathematics curriculum for Bulgarian primary schools is based on the decimal number system. The pupils perform elementary arithmetic operations while solving numerical examples, simple linear equations or inequalities, and story (or word) problems. In mathematical story problems, numerical data and logical relations are interwoven in real life situations described through a narrative. To deal with them successfully, the primary school children need to acquire comprehensive reading skills. They help them separate what is given from what is sought, recognize mathematical concepts and decide what operations to perform. In essence, these activities are mathematical modeling, which makes solving story problems crucial for building the little students' modern mathematical literacy.

1 gorcheva@math.bas.bg 
For years the researchers in mathematics education like Pollak (Pollak, 2007), Niss (Niss, 2012), Stillman et al. (Stillman et al., 2013), Spandaw and Zwaneveld (Spandaw and Zwaneveld, 2010) and many others have been emphasizing the importance of teaching and learning of mathematical modeling in school. The authors of mathematical textbooks make significant efforts to prepare the pupils for the challenges of problem solving: after each unit they offer numerous story problems, which differ by the level of difficulty and allow the teachers to meet their students' needs. Math competitions have had a significant share in raising the students' mathematical literacy as well. At the beginning of each school year the Bulgarian Ministry of Education and Sciences issues an official schedule of all upcoming competitions and olympiads. ${ }^{2}$ To train their students, the mathematics teachers organize circles where the children not only solve problems and learn extracurricular mathematical topics, but also make new acquaintances. In such a way mathematics turns into a subject that creates social networks among teachers, students, and parents.

The socializing effect of mathematical modeling for elementary schoolchildren was noticed and reported by Pollak (Pollak, 2007). Long before him, the Bulgarian man of letters Dimitar Stoyanov known by his pseudonym Elin Pelin also realized that very effect of mathematical problem solving. Although with no professional training in mathematics, he turned the spreading of mathematical literacy through a children's newspaper into his mission.

\section{Writer Elin Pelin and his mathematical story- problems}

According to Rothschild, Elin Pelin is Bulgaria's "most popular interwar author", who wrote

2 Bulgarian Ministry of Education and Sciences. Order No. 1505 from September 30, 2014 about School olympiads and national competitions. Retrieved October 10, 2014. from http:// www.mon.bg "superb children's stories and poems" (Rothschild, 1974: 395). Elin Pelin (in Bulgarian: Елин Пелин, 1877-1949) dreamed to be an artist, but became one of the most renowned Bulgarian writers who painted his images in words. Since the age of 17 , for several years he worked as a teacher in his native village where he watched the children play, study and interact with their peers. This first hand experience inspired many of the fascinating plots and characters in his later stories.

Elin Pelin was also a publisher. In the mid1930s he issued the children's newspaper Path (in Bulgarian: Пътека) where he regularly included mathematical story problems. They are now collected in a small book (Elin Pelin and Podvarzachov, 1992) published posthumously by his son. The main character in these stories is Old-hand Stanyo who asks his neighbors' children to solve problems that test their logical thinking, wit, and attention to detail. They often exceed in length and totally differ from ordinary textbook problems. Most of them are fairly easy to solve; others challenge even professional mathematicians and educators. What unites them is their reverence to mathematical literacy, common sense and nuances in speech. The stories are evidence of the type of mathematical knowledge the common people of the time regarded helpful to overcome the obstacles of life. I implemented many of them in my seminars with the prospective primary school teachers from the Department of Preschool and Primary school education at Sofia University "St. Kliment Ohridski".

\section{Elin Pelin's approach to problem formulation}

All students I worked with knew a lot about Elin Pelin's literary works, but no one had heard about his story problems. The example I used as a warm-up activity was more of a story than a mathematical problem and vividly demonstrated the culture of farmers' life and the nature of everyday problems at the time: 
Story problem 1. "It was last summer," Oldhand Stanyo began his story. "I was walking down the Pirin mountain, heading for the plain. On a paddock I saw two horses grazing. The stud was tall and black, robust, with a broad saddle and sleek fur. Although his tail was missing, he looked like a pedigree animal. The mare was very beautiful too - of a local breed, a little short, immaculately white, you just could not help stroking her, with streamers intertwined to decorate her magnificent tail. A really gorgeous animal!

A few steps away, three guys were bickering about something, waving their arms... It turned out they were having an argument. Two of them were travelers. They had come to that place at noon in the sweltering heat and left their horses to graze on the paddock while they took a nap in the shadow. Meanwhile the owner of the paddock came from the nearby village, woke them up and demanded that they pay him for the grazing of their horses. The travelers agreed. One of them dug into his pocket and produced 10 levs ${ }^{3}$ which the villager willingly took. Yet when the other traveler handed him his 10 levs, he refused to accept it."

"It is too little," he said. "Ten levs for the stud is a fair deal, but not for the mare. For her, if not 20, you should pay me at least 15 levs."

No matter how hard they tried to persuade him, he would not agree. Therefore they summoned me to settle the dispute.

"Well, and did you, uncle Stanyo?"

"I said straight away that the villager was right beyond a shadow of a doubt. Why do you, buddies, think I supported his opinion?" (Problem 4, Elin Pelin and Podvarzachov, 1992: 15-16)

This small literary masterpiece not only excited the future primary school teachers, but also puzzled them: they were not sure whether it can be classified as a mathematical story problem. The following speculations by Novakova (Novakova, 2003) shed light on the case, allowing the students to form their own opinions: "In order to have a story problem, there has to be a requirement (a question) that defines what is sought." (Novakova, 2003: 165). In Story problem 1 such a question existed. The answer was also provided, which was not quite usual for problem formulation. Elin Pelin did it for a purpose - to boost the logical thinking of his readers. My audience reasoned out loud that the mare had to eat up more grass than the stud since more money had been demanded for her grazing. One of the students noted that in the wild animals do not overeat. Thus the idea that the mare could have been pregnant came up and the prospective teachers, most of whom were female, adopted that explanation. Their inference was plausible and Old-hand Stanyo would have probably accepted it. However, his reasoning differed: "The stud's tail was missing while the mare's tail was long and even had streamers for decoration. Thus the mare was able to easily keep the flies away and graze undisturbed, while the stud, continuously being pestered by the insects was able to pasture less. Therefore, the villager was right to want more money for the mare's grazing." (Elin Pelin and Podvarzachov, 1992: 80).

The students did not expect such a turn of events. They became aware how skillfully Elin Pelin had led them to this conclusion: describing the stud's missing and mare's magnificent tail, he was giving them a key to his point of view. They realized that writing his story and formulating the problem, the great writer had in mind both the concept and the solution. Thus the future teachers received a lesson in paying attention to detail and context.

One of Elin Pelin's noble ambitions as a publisher was to bring the culture of the world to the poor children from the smallest villages in Bulgaria. He created a story in which he told them about the enchanting nature of the Far East. But the readers would soon realize that the landscape and animals were just a background:

3 Lev (in Bulgarian: лев) is the name of Bulgarian currency. 
Story problem 2. Once upon a time in China, on the bank of the Great River Yangtze, a boatman named $\mathrm{Ha}$-de lived with his 10-year-old son $\mathrm{Pu}-$ pi. Ha-de built himself a large and strong boat and made his living by carrying bricks to the opposite bank of the river. There the mandarin Ah Ti-Vrag was having a new palace built.

The mandarin was very mean. One day he called Ha-de and told him:

"Listen to my order! Tomorrow you must tell me how much my favorite elephant Sambo weighs. Otherwise you'll be in trouble."

The boatman panicked: he did not have such big scales to weigh an elephant on them. Desperate, Ha-de told his son about this impossible task. Pu-pi just laughed; he was sure that his father could deal with it. And here is what happened: the next day Hade stepped before the mandarin and told him exactly how much his favorite elephant Sambo weighed.

How do you think the boatman and his son managed to find the weight of the elephant? (Problem 1, Elin Pelin and Podvarzachov, 1992: 8-9)

The situation described was again unexpected for the undergraduate students and for a while they pondered how to approach the problem. Another reading of the text and the practice with the previous problem led them to carefully interpret the information which the expressions "he built a large and string boat" and "he did not have such big scales" carried. They concluded that the boatman had to have some scales, although not big enough to weigh an elephant on them, but pretty good to identify the weight of a brick, for example. Thus they almost reached the solution Elin Pelin had in mind: "Pu-pi, the boatman's son, hauled the boat into the water, lured Sambo inside it and drew a line on the boat's outer side to mark the level of the water. Then $\mathrm{Pu}$-pi took Sambo back to the bank and began to load the boat with bricks until the water reached the mark; then he weighed one brick on the scales, counted the bricks in the boat and calculated the elephant's weight." (Elin Pelin and Podvarzachov, 1992: 80).

I asked the students to collectively formulate Elin Pelin's problem as it could be written for a modern primary school textbook, and make a comparison with the original version. The text unanimously suggested was:

Students' version of Story problem 2. A single brick weighs $3 \mathrm{~kg}$. How many kilograms do 1,200 such bricks weigh?

The future teachers' comments on their own version were that it was "mathematically precise, doable in a minute, free of emotion and boring", because "no insight is needed for this problem to be solved." One student expressed an interesting opinion: "Through this story problem Elin Pelin sends a message to the children that mathematics is not an isolated subject. That is what is missing in our version."

The literary works which Elin Pelin left document various aspects of common people's life in the period between the two world wars, including their financial hardships. As the text of Story problem 1 reveals, they count every penny and negotiate each bargain. Understanding the importance of interpersonal relations which occur at the markets, the writer uses this environment as a setting for several of his story problems. From Old-hand Stanyo's next story contemporary readers learn that buying chocolate to a child was a rare event: a reward or maybe a bribe for proper behavior. The humorous plot aims not only to provide mathematical knowledge to the children, but to instill good manners in them and teach them respect for parents and grandparents:

Story problem 3. My grandson Mitko is a very spoilt child. This morning my wife and I headed for the market. As loving grandparents do, we took Mitko with us to spend the day together, but he became a pain in the neck: whichever store we stopped by, Mitko always wanted us to buy him a present.

In a grocery store I accidentally saw big scales and asked the seller to check my weight. I was just 
about to step on the scales, when Mitko grabbed my pants: scales!"

"Grandpa, I want to be with you on the

"Let me first weigh myself, buddy. Then I'll weigh you as well."

No matter how hard I tried to persuade my grandson, even by buying him chocolate - he did not agree to get off the scales. I was forced to give in. I allowed Mitko to weigh with me and the scales showed $111 \mathrm{~kg}$. After we got off them, I called my wife to quickly weigh herself while I was entertaining the troublemaker Mitko. But he caught her skirt and did not drop it until he stepped on the scales again with her. Thus both Mitko and grandma's weight together came exactly to $82 \mathrm{~kg}$.

"So you and your wife did not weigh separately, uncle Stanyo?"

$$
\begin{aligned}
& 111 \mathrm{~kg}-\text { grandpa and Mitko } \\
& 82 \mathrm{~kg}-\text { grandma and Mitko } \\
& 139 \mathrm{~kg}-\text { grandma and grandpa } \\
& \begin{aligned}
111+82 & =193 \\
& -\frac{139}{54} \div 2=27 \mathrm{~kg} \\
2(\text { grandpa } & + \text { grandma }+ \text { Mitko) }=332 \\
\text { grandpa } & + \text { grandma }+ \text { Mitko }=166 \mathrm{~kg} \\
& 166 \\
& -\frac{111}{55}-\text { grandma } \\
& 166 \\
& \frac{139}{27}-\text { grandson }
\end{aligned}
\end{aligned}
$$

Figure 1. A solution to Story problem 3 by a prospective primary school teacher (left - the original excerpt; right - the English translation)

"No, we didn't. We barely managed to get together on the scales. Thus both grandma and grandpa, without Mitko, weighed $139 \mathrm{~kg}$. Tell me now, how many kilograms each and every one of the three of us weighs." (Problem 16, Elin Pelin and Podvarzachov, 1992: 45-46)

Probably the most straightforward way to approach this problem is to use a system of linear equations, but the topic is not included in Bulgarian primary school mathematics curriculum. Therefore the undergraduate students were to step into children's shoes.

As Figure 1 shows, the solution process was not smooth for everybody. Pretending to have only a little pupil's mathematical knowledge was tense for the particular prospective teacher: she obtained the same answer twice (Mitko's weight), but unintentionally omitted to point out the third answer required (the grandfather's weight). 
Elin Pelin loved to be in line with the latest developments in science and technology. In an unpublished telephone interview from 2006 with Elin Pelin's son - Mr. Boyan Dimitrov, - I learned a lot about the great writer's interest in science and technology. He subscribed to the journal "Science" and took many of his ideas from it; he assembled three radio sets all by himself; he regularly went to the market and as he was a keen observer and an attentive listener, he probably borrowed ideas and characters to later implement in his story problems. In the last narrative discussed here the knowledgeable reader will recognize the characters from the fairy tale "One-eye, Two-eyes, and Three-eyes" published in 1812 by Brothers Jacob and Wilhelm Grimm (Grimm, 1909-1914). What makes Elin Pelin's story unique is its mathematical content that cannot be found in the original Brother Grimm's tale.

Story problem 4. Once upon a time there lived an old and cruel witch. She had three daughters. The first had only one eye placed in the middle of her forehead; the second had three eyes and the third two eyes, just like other people do. The old witch loved the One-Eyed and the Three-Eyed daughters, but hated the Two-Eyed one: maybe because she was the most beautiful and her two eyes were just in their right places.

One day the witch called her three girls and gave them apples: 50 wonderful apples to the OneEyed, 30 wonderful apples to the Three-Eyed and only 10 unripe and wrinkled apples to the Two-Eyed.

"Now, girls, go immediately to the market and sell all your apples," she ordered them. "However, make sure that each of your brings back the same amount of money!"

The Two-eyed daughter was scared: "O Mom! I cannot earn as much money for my wrinkled 10 apples as my sisters for their pretty 50 and 30 apples."

"Shut up!" chided the old hag. "If you bring even a penny less than your sisters, you will be in trouble!"
The Two-Eyed girl began to cry: "Then let me sell my apples at a higher price than them."

The old woman scolded again: "Listen! If you dare sell at a price even a penny higher than your sisters' prices, I will punish you. Go!"

The three girls headed for the market: The One-Eyed and the Three-Eyed sisters, dressed up and dolled up, ran ahead, laughing. Their Two-Eyed sister, wearing her only faded cotton dress, dragged behind, crying miserably. Thus the wretch was left a whole kilometer behind her sisters. Meanwhile, her beloved golden-horned goat caught up with her and turned the ten wrinkled apples into ten irresistibly fresh and juicy ones.

What happened later? Soon the Two-Eyed sister reached the market and stood there next to her sisters. Whatever price they had asked for their apples, the same price she wanted for hers. At the end of the day, although The One-Eyed sister sold 50 apples, The Three-Eyed sold 30 apples, and The TwoEyed one sold only 10 apples, the three girls earned an equal amount of money and brought it back to their mother.

At what price, do you think, the three sisters sold their apples to fulfil the demands of their witch mother? (Problem 9, Elin Pelin and Podvarzachov, 1992: 29-30)

When the prospective primary school teachers read the problem from their handouts, they were puzzled saying it was unsolvable. Several female students suggested reading it again, in parts, changing their voices appropriately. The careful analysis of the text revealed that a clue to model the situation mathematically still existed: it was to decipher not only what was told to the readers, but also to guess what was not told. The only thing the mother required was that all the sisters demanded equal prices for their apples at the market. For example, they were not forbidden to change the prices. Thus a two-stage sale of a different number of apples could bring the same revenue to the girls. 


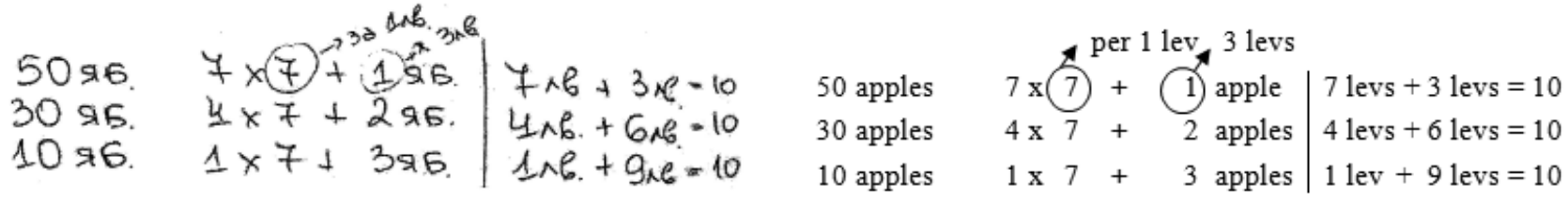

Figure 2. Elin Pelin's solution to Story problem 4, written by a student

(left - the original excerpt; right - the English translation)

Elin Pelin provided such a solution which I showed to the audience. We discussed it for a long time because the undergraduate students had difficulty believing it was possible. In the end they realized the problem had a solution (Figure 2).

The students' surprise was even bigger when I demonstrated a few more solutions obtained by the method of linear programming (Kelevedjiev and Gortcheva, 2010). The students were fascinated by the existence, as well as by the potential of this method. Tables 1 and 2 show two such solutions.
I assigned the undergraduate students to create again their formulation of the problem. Collectively, they produced the following text:

Students' version of Story problem 4. A retailer rents a store in three city locations and pays the same rent for each. Today he sells top fashion T-shirts, at the same prices in all three stores. In the first store there are $50 \mathrm{~T}$-shirts to sell, in the second - 30, in the third -10 . As the rents he pays are equal, he wants to have the same revenue from each store, keeping the prices equal at every moment of the sale. At what prices can the retailer sell the T-shirts in order to ensure the same revenue from the three stores?

Table 1. A sale in which every sister can earn 70 levs

\begin{tabular}{|c|c|c|c|c|c|c|}
\hline Daughter & $\begin{array}{c}\text { Number of } \\
\text { apples }\end{array}$ & First price & Apples sold & Second price & Apples sold & Revenue \\
\hline One-eyed & 50 & \multirow{3}{*}{$\begin{array}{c}1 \text { apple per } \\
1 \text { lev }\end{array}$} & 48 & \multirow{3}{*}{$\begin{array}{c}1 \text { apple per } \\
11 \text { levs }\end{array}$} & 2 & 48 levs +22 levs \\
\hline Three-eyed & 30 & & 26 & & 4 & 26 levs +44 levs \\
\hline Two-eyed & 10 & & 4 & & 6 & 4 levs +66 levs \\
\hline
\end{tabular}

Table 2. A sale in which every sister can earn 100 levs

\begin{tabular}{|c|c|c|c|c|c|c|}
\hline Daughter & $\begin{array}{c}\text { Number of } \\
\text { apples }\end{array}$ & First price & Apples sold & Second price & Apples sold & Revenue \\
\hline One-eyed & 50 & \multirow{3}{*}{$\begin{array}{c}1 \text { apple per } \\
1 \mathrm{lev}\end{array}$} & 45 & \multirow{3}{*}{$\begin{array}{c}1 \text { apple per } \\
11 \text { levs }\end{array}$} & 5 & 45 levs +55 levs \\
\hline Three-eyed & 30 & & 23 & & 7 & 23 levs +77 levs \\
\hline Two-eyed & 10 & & 1 & & 99 & $1 \mathrm{lev}+99$ levs \\
\hline
\end{tabular}


Asked to compare the two versions of the problem, the undergraduate students, mostly young ladies with vast shopping experience, found the Tshirt version more realistic. They eagerly discussed: "Even if we hadn't been able to reach such exact solutions, we would have invented at least a strategy to them."

\section{Discussion of the results}

The selection of Elin Pelin's story problems which I present herein gives an idea about the writer's interest in mathematics and sciences, but their scope remains uncovered. Fortunately, I managed to introduce the majority of the story problems to the students at my seminars. They all enjoyed his ingenuous ways to imbed concepts like divisibility of numbers, binary number representation, Diophantine equations, graph theory, permutations, or Cartesian coordinate system in fabulous stories about animals, rascals, buckets of water, navy ships... Although not so frequently, ideas from science and technology were also found there, as well as literature related tasks.

Initially I was concerned whether using such old-fashioned story-problems was justifiable in $21^{\text {st }}$ century teacher education and in its projection primary school education. Confirmation came from the students. Here is how they reflected on them:

Student 1: "I never imagined that Elin Pelin could write math problems for children."

Student 2: "I changed my opinion about men of letters which only at first glance did not understand maths."

Student 3: "From a literary point of view the writer did a perfect job: while Old-hand Stanyo talked, the children listened to him to realize in the end that it was not just a story, but a problem to be solved. As a reader I felt the same way."
Student 4: "If all word problems had been represented in such manner, mathematics would have been my favourite subject at school."

The fact that a group of undergraduate students started impulsively reading out loud Story problem 4 because it seemed unsolvable to them can be interpreted as a form of "expressive engagement" (Sipe, 2002): by immersing themselves in the plot the prospective teachers tried to "dominate the text" (Sipe, 2002), i.e. to solve the problem.

I observed the same motivating effect on the students of all Elin Pelin's story problems. In my opinion, to great extent it was due to their unique cultural messages which my audience with a background primarily in humanities highly valued.

As reported by Lindgren and Bleicher (2005), many future elementary school teachers find science content courses "boring or difficult, with little relevance to their lives or to teaching children" (Lindgren and Bleicher, 2005). Therefore, situations like the one described in Story problem 2 boost students' interest in science and make them search for more practical problems and connections among school subjects.

My experience shows that Elin Pelin's story problems can be successfully used even as a source for a drama project in primary school (Gortcheva, 2014). For such a purpose, it is not necessary to literally use the texts, but only the way mathematical ideas have been intertwined.

\section{Concluding remarks}

Through their specific contents Elin Pelin's story problems help contemporary readers touch the culture and lifestyle of common Bulgarian people from the period between the two world wars and learn about mathematical knowledge and skills they needed most. Properly balanced, these problems still have place in modern primary school education, as well as in core subject courses for prospective teachers. They challenge even profession- 
al mathematicians to model the nonstandard situations described. The multiple solutions which some problems allow make them appropriate for implementing inquiry based learning in the classrooms.

Elin Pelin's story problems can serve teachers to effectively combine the traditional " $3 \mathrm{Rs"} \mathrm{of} \mathrm{pri-}$ mary school education: Reading, wRiting and aRithmetic. The reading skills developed by such texts are crucial for children's success in problem solving. By focusing both on the context and detail, they help pupils analyze situations, find numerical and logical data in texts, get rid of unnecessary information, and answer questions. To communicate their mathematical knowledge, students should possess strong writing and oral skills. Only then will they be able to persuasively express their opinions and results on paper, in files, presentations, blogs, social networks, podcasts... And here come to help the messages of Elin Pelin's story problems to their young readers: to study hard in order to have things to say and write about.

\section{Acknowledgements}

The author sincerely thanks Prof. Zdravko Lalchev from the Department of Pre-school and Primary school education at Sofia University "St. Kliment Ohridski” for his support and his undergraduate students for their enthusiastic participation.

\section{References}

- Elin Pelin and Podvarzachov, D. (1992). Бай Станьо Познавача: Разкази-задачи (Old-hand Stanyo: Storyproblems). Sofia: Language and Culture.

- Gortcheva, I. (2014). Word problems on stage: An appealing approach to inquiry-based learning and bridge to humanities. Educational Policies in the 21 $1^{\text {st }}$ Century. Proceedings of the International Conference (59-65). Sofia: Center for Creative Training. Retrieved October 10, 2014 from http://edu21 project.eu/files/download/ EDU21-ConferenceProceedings.pdf

- Grimm, J. and W. (1909-1914). Household Tales. In: Eliot, C. W. (ed.). The Harvard Classics, 17 (2). New York: P. F. Collier \& Son. Retrieved October 10, 2014 from http://www.bartleby.com/17/2

- Kelevedjiev, E. and Gortcheva, I. (2010). Method of linear programming as an idea for high school curriculum. In: Russev, P. et al. (eds.), Mathematics and Education in Mathematics. Proceedings of the $39^{\text {th }}$ Spring Conference of the Union of Bulgarian Mathematicians (49-62). Sofia: Union of Bulgarian Mathematicians. Retrieved October 10, 2014 from http://www.math.bas.bg/smb/2010_PK/tom/pdf/049-062.pdf

- Lindgren, J. and Bleicher, R. E. (2005). Learning the learning cycle: The differential effect on elementary preservice teachers. School science and mathematics, 105(2), 61-72.

- Niss, M. (2012). Models and modelling in mathematics education. Newsletter of the European Mathematical Society, 86, 49-52.

- Novakova, Z. (2003). Методика на обучението по математика в началните класове (Methods of teaching mathematics at primary school). Plovdiv: Hermes.

- Pollak, H. (2007). Mathematical modelling - a conversation with Henry Pollak. In: Blum, W. et al. (ed.), Modelling and applications in mathematics education: The $14^{\text {th }}$ ICMI study (109-120). New York: Springer.

- Rothschild, J. (1974). East Central Europe between the Two World Wars. Seattle: University of Washington Press. 
- Sipe, L. R. (2002). Talking back and talking over: Young children's expressive engagement during storybook read-alouds. The Reading Teacher, 55(5), 476-483. Retrieved October 10, 2014 from http://www.readingonline.org/electronic/rwt/sipe/sipe.pdf

- Spandaw, J. and Zwaneveld, B. (2010). Modelling in mathematics teachers' professional development. In: Durand-Guerrier, V., Soury-Lavergne, S. and Arzarello, F. (ed.), Proceedings of the Sixth Congress of the European Society for Research in Mathematics (2076-2085). Lyon: Unversité 1 de Lyon.

- Stillman, G., Brown, J. and Galbraith, P. (2013). Identifying challenges within transition phases of mathematical modeling activities at year 9. In: Lesh, R. et al. (ed.), Modeling students' mathematical modeling competences (384-398). Dordrecht: Springer.

\section{др Јорданка Гочева}

Институт за математику и информатику бугарске Академије наука,

Одељење за образовање, Софија, Бугарска

\section{Математичке и културне поруке из периода између два светска рата - проблеми текстуалних задатака Елина Пелина}

Математички курикулум бугарских основних школа је заснован на децималном бројном систему. Ученици обављају основне аритметичке операције са бројевима, решавају једноставне линеарне једначине и неједначине, као и текстуалне задатке. Код ових задатака преплићу се бројчани подаци и логички односи у свакодневним ситуацијама, што је описано у раду. Да би успешно решавали текстуалне задатке, ученици морају да направе разлику између онога што је дато и онога шта се тражи, да препознају математички појам у тексту и да одлуче које математичке операције треба да користе да би дошли до решења. С обзиром на то да је основа ових активности математичко моделовање, решавање текстуалних задатака је основно за формирање математичке писмености ученика нижих разреда. Годинама су истраживачи математичког образовања, као што су Полак (Pollak, 2007), Нис (Niss, 2012), Стилман и др. (Stillman et al., 2013), Спандау и Званевелд (Spandaw and Zwaneveld, 2010) и многи други, истицали важност поучавања и учења математичког моделовања у школи. Аутори модерних математичких уџбеника су начинили велике напоре да припреме ученике за изазове решавања математичких задатака - после сваке лекције понудили су много текстуалних задатака који се разликују по нивоу и тежини и тиме омогућавају наставницима да помогну ученицима. И математичка такмичења су имала важан удео у побољшавању математичке писмености ученика. Да би спремили ученике за учешће на такмичењима, наставници математике су организовали секције у којима ученици не само да су решавали проблеме и учили о темама ван наставног програма већ су склапала и нова познанства. Тако се математика претворила у предмет који је омогућио дружење међу наставницима, ученицима и родитељима. Ефекат социјализације математичког моделовања код деце основношколског узраста приметио је и објавио Полак (Pollak, 2007). Давно пре њега, бугарски учењак без професионалног знања математике схватио је тај ефекат математичког решавања проблема. Тај интелектуалац је био Елин Пелин (1877-1949). Желео је да постане уметник, али је судбина хтела да слика речима. Према Ротшилду (Rothschild, 1974), био је бугарски „најпопуларнији аутор између два рата“, који је писао „дивне дечје 
приче и песме“ (Rothschild, 1974: 395). Елин Пелин је прихватио ширење математичке писмености међу бугарским ученицима као мисију. Средином тридесетих година 20. века покренуо је дечји часопис „Стаза“ (на бугарском „Пътека”) (1932-1936), редовно објављујући математичке текстуалне задатке. Они су сада прикупљени у књижици (Pelin \& Podvarzachov, 1992), коју је постхумно објавио његов син. Њихово сликовито излагање и суштина су били много различити од текстуалних задатка у уџбеницима математике. Главна личност, стара Шака Стањо, волела је да прича комшијској деци приче у којима су се преплитали елементи математике и логике. Понекад су били сувише дуги, али су текстуални задаци откривали различите стране културе деци и учили су их како да обрате пажњу на детаље, да логички размишљају и да не запостављају здрав разум. Какве год ситуације да су биле описане, поука је била увек иста - математичка писменост је помагала да се превазиђу животне препреке. Часопис „Стаза“ се читао по целој Бугарској и инспирисао је децу из великих и малих градова да уче да броје, да сазнају о дељивости бројева, системима и линеарним једначина, бинарном бројном систему итд. Стога су текстуални задаци Елина Пелина доказ врсте математичког знања обичних људи, које може да се сматра драгоценим. Мој рад са студентима на основним студијама и са постдипломцима показао је да, иако нису били модерни, текстуални задаци Елина Пелина су привлачили пажњу читалаца. У знатној мери, разлог томе су елементи културе у периоду између два рата и математичке поруке које њихове јединствене формулације и решења садрже. Као велики писац, Елин Пелин је предвидео шта ће бити занимљиво за следеће генерације и како ће деца гајити вредности као њихови родитељи, баке и деке.

Клучне речи: Елин Пелин, основна школа, текстуални задаци, математички појмови, култура. 